\title{
Integrated House Fly Control: Populations of Fly Larvae and Predaceous Mites, Macrocheles muscaedomesticae, in Poultry Manure After Larvicide Treatment ${ }^{1}$
}

\author{
Richard C. Axtell ${ }^{2}$ \\ Department of Entomology, North Carolina State University, Raleigh
}

\section{ABSTRACT}

The populations of 3rd-instar larvae of house fly, Musca domestica L., and adults of Macrocheles muscaedomesticae (Scopoli) (Acarina: Macrochelidae), which are predaceous on the eggs and 1st-instar larvae of the house fly, were determined at intervals before and after the application of 12 insecticides to the manure under caged laying hens. Selective toxicities which could be used to advantage in larviciding for fly control were not found. The few chemicals which did not destroy the mite population gave very little control of fly larvae, while those which gave some control of fly larvae (for periods up to 2 weeks) were deleterious to the mite population. The mite population increased very slowly following decimation by insecticide treatment, while the numbers of fly larvae increased rapidly.

It was concluded that larviciding of the manure with nonselective insecticides is detrimental to mite predators of the immature stages of the house fly and should not be practiced. Selective application methods for adult fly control are preferable and efforts to refine these methods should be intensified.
House flies, Musca domestica L., commonly develop in large numbers in poultry manure under caged hens and their control is a perennial problem. The inadequacy of present control measures (Anderson 1966) has prompted more intensive investigations of fly behavior (Anderson 1964, 1965; Anderson and Poorbaugh 1964; Keiding 1965) and of the biological control agents which may be integrated into a house fly control program (Axtell 1963, 1964; Farish and

1 Supported in part by U.S. Public Health Service Research Grant 9 R01 Sw00020 from the Office of Solid Wastes. Statistical analysis was performed with computor facilities supported in part by Public Health Service Grant FR-00011. The assistance of T. D. Edwards, M. G. Karandinos, R. R. Willis, and J. Hunt are acknowledged. Contribution from the Entomology Department, North Carolina Agricultural Experiment Station, Raleigh. Published with the approval of the Director of Research, Paper no. 2450 of the Journal Series. Accepted for publication October 15, 1967

2 Associate Professor.
Axtell 1966; Kinn 1966; Legner 1966; Legner and Brydon 1966; Legner and McCoy 1966; McCoy 1965; O'Donnell and Axtell 1965; Singh et al. 1966) .

Among these agents are various species of manureinhabiting, predaceous mites of the family Macrochelidae which feed on the eggs and lst-instar larvae of the house fly. The commonest species, Macrocheles muscaedomesticae (Scopoli), has been shown in laboratory tests to be susceptible to most insecticides which are or have been used for house fly control (Axtell 1966). Unfortunately, although larviciding of the manure for fly control may not be commonly recommended, it is frequently practiced by the producer, and directions are included on the labels of many insecticides sold for fly control. In addition, chemicals are being evaluated as house fly larvicides in poultry manure without evaluating their effects on 
Table 1.-Populations of mites ( M. muscaedomesticae) and house fly larvae in poultry manure $60 \mathrm{~cm}$ deep following application of larvicides.

\begin{tabular}{|c|c|c|c|c|c|c|c|}
\hline \multirow[b]{3}{*}{ Chemical } & \multirow{3}{*}{$\begin{array}{c}\text { Concn }^{\mathrm{a}} \\
(\%)\end{array}$} & \multicolumn{3}{|c|}{ Mean no. mites/sampleb } & \multicolumn{3}{|c|}{ Mean no. fly larvae/sampleb } \\
\hline & & \multirow[b]{2}{*}{ Pretrt. } & \multicolumn{2}{|c|}{ Days after treatment } & \multirow[b]{2}{*}{ Pretrt. } & \multicolumn{2}{|c|}{ Days after treatment } \\
\hline & & & 5 & 13 & & 5 & 13 \\
\hline Dimethoate & 1.0 & $49.6 \mathrm{e}$ & $0.8 \mathrm{a}$ & $11.2 \mathrm{~b}$ & $21.7 \mathrm{a}$ & $0.5 \mathrm{a}$ & $83.5 \mathrm{~b}$ \\
\hline Fenthion & 1.0 & $37.0 \mathrm{~d}$ & $1.9 \mathrm{a}$ & $0.0 \mathrm{a}$ & $22.0 \mathrm{a}$ & $4.5 \mathrm{ab}$ & $14.8 \mathrm{ab}$ \\
\hline Diazinon & 0.5 & $35.4 \mathrm{~d}$ & $2.3 \mathrm{a}$ & $1.2 \mathrm{a}$ & $17.5 \mathrm{a}$ & $3.5 \mathrm{a}$ & $55.8 \mathrm{~b}$ \\
\hline Bay 39007 & 1.0 & $29.7 \mathrm{bc}$ & $3.4 \mathrm{a}$ & $10.5 \mathrm{~b}$ & $16.3 \mathrm{a}$ & $1.4 \mathrm{a}$ & $51.9 \mathrm{~b}$ \\
\hline Ronnel & 1.0 & $53.8 \mathrm{f}$ & $4.7 \mathrm{a}$ & $.6 \mathrm{a}$ & $35.1 \mathrm{a}$ & $24.5 \mathrm{~b}$ & $34.2 \mathrm{~b}$ \\
\hline Malathion & 1.0 & $27.3 \mathrm{a}$ & $9.5 \mathrm{ab}$ & $24.0 \mathrm{~b}$ & $7.8 \mathrm{a}$ & $45.4 \mathrm{bc}$ & $2.9 \mathrm{a}$ \\
\hline Kepone & 3.0 & $28.0 \mathrm{ab}$ & $16.6 \mathrm{~b}$ & $24.6 \mathrm{bc}$ & $16.0 \mathrm{a}$ & $2.8 \mathrm{a}$ & $9.1 \mathrm{a}$ \\
\hline Dichlorvos & .5 & $31.1 \mathrm{c}$ & $18.2 \mathrm{~b}$ & $32.7 \mathrm{c}$ & $11.6 \mathrm{a}$ & $109.6 \mathrm{c}$ & $9.0 \mathrm{a}$ \\
\hline Ciodrin & 1.0 & $37.1 \mathrm{~d}$ & $38.3 \mathrm{bc}$ & $25.6 \mathrm{c}$ & $32.3 \mathrm{a}$ & $70.6 \mathrm{c}$ & $2.8 \mathrm{a}$ \\
\hline Naled & 1.0 & $34.8 \mathrm{~d}$ & $88.7 \mathrm{c}$ & $48.5 \mathrm{c}$ & $19.8 \mathrm{a}$ & $322.0 \mathrm{c}$ & $8.1 \mathrm{a}$ \\
\hline Untreated (water) & & $47.3 \mathrm{e}$ & $79.9 \mathrm{c}$ & $84.3 \mathrm{c}$ & $11.8 \mathrm{a}$ & $19.6 \mathrm{~b}$ & $24.2 \mathrm{~b}$ \\
\hline Untreated & & $27.1 \mathrm{a}$ & $87.5 \mathrm{c}$ & $44.2 \mathrm{c}$ & 24.8 a & $12.2 \mathrm{~b}$ & $10.5 \mathrm{a}$ \\
\hline
\end{tabular}

a Applied by sprinkling can at the rate of 0.5 liter $/ \mathrm{m}^{2}$. Pretreatment counts June 23. Treated June 24. Manure accumulated since October.

Each mean was based on 4 replicates. Data were transformed to $\ln (\mathrm{X}+1)$ prior to analysis of varia
same letter in each column were not significantly different at the $5 \%$ level (Duncan's multiple range test).

the biological control agents (Brady and LaBrecque 1966). Therefore, applications were made to the manure under caged hens, and the resultant effects on the populations of $M$. muscaedomesticae and house fly larvae were determined.

Materials and Methods.-All experiments were conducted during June-August 1966 in 4 adjacent poultry houses $(3 \mathrm{~m}$ wide $\times 100 \mathrm{~m}$ long) near Apex, N. C. Each house had open sides and 1 row of wire cages on each side of a center concrete aisle. The cages, containing 3 birds each, were suspended $1 \mathrm{~m}$ above the compacted dirt floor. The manure-containing area between alternate posts was a replicate $\left(5 \mathrm{~m}^{2}\right)$. A randomized complete block design was used in all experiments. Each treatment was replicated 4 times in Experiments 1, 2, 3, and 4; and 6 times in Experiment 5.

The numbers of adult mites and 3rd-instar house fly larvae were determined by spreading a 0.5 -liter scoop of the manure thinly in a large white enamel pan in the sunlight and counting all observable individuals. The total from 3 scoops comprised the sample from each replicate. These subsamples were taken by 3 different persons from the center of the replicate where conditions appeared most favorable for both mites and fly larvae. Samples were taken no longer than 1 day prior to insecticide application and at several intervals of 5-30 days after treatment. Microscopic examination of aliquots of the mites and fly larvae at intervals throughout the period of the experiments confirmed the identities of the species. Lesser numbers of predaceous mites of the families Uropodidae and Parasitidae were present, but were not counted.

Water dilutions of the chemicals (wettable powder of Kepone ${ }^{\circledR 3}$ and emulsifiable concentrates of others) were applied to the manure by sprinkler cans at various volumes according to the depth and dryness of the manure. This method of application minimized any problems of insecticide drift to adjacent areas. Dry formulations of chemicals were applied by hand. The formulations used and sources of chemicals are presented at the end of this report.

Experiment 1.-Ten chemicals were applied at the rate of 1.5 liter $/ \mathrm{m}^{2}$ to the manure in house 1 on June 29 at concentrations that could reasonably be expected to control fly larvae $(0.5-3 \%$ depending on the chemical). The manure had accumulated overwinter and was $60 \mathrm{~cm}$ deep. Fly larvae and M. muscaedomesticae were abundant.

Experiment 2.-Upon completion of Experiment 1, the manure was removed from house 1 on July 14 and fresh manure was allowed to accumulate for 3 weeks. Fly larvae and mites became abundant during this insecticide-free period. Each chemical was applied at the same concentration and to the same areas of the house as were used in Experiment 1. However, the volume was reduced to 0.5 liter $/ \mathrm{m}^{2}$, since the depth of the manure was only $5 \mathrm{~cm}$.

Experiment 3.-1\% and $0.5 \%$ SD 8447 was applied to the manure on 1 side of house 3 at the rate of 0.5 liter $/ \mathrm{m}^{2}$. Treatment was made on August 19, when the manure had accumulated since July 26 and was $7 \mathrm{~cm}$ deep.

Experiment 4.-Kepone wettable powder and granular formulations of diazinon and Zytron ("Fly Granules") were broadcast on a l-month accumulation of very moist manure $(15 \mathrm{~cm}$ deep) in house 4. The experiment was discontinued when the manure became extremely wet (because of leaking water systems and the nervous nature of the particular strain of hens).

Experiment 5.-Zytron granules were further evaluated at 2 application rates in house 2. Treatment was made August 5 when the manure had accumulated since July 11 and was $5 \mathrm{~cm}$ deep. Concurrently, Zytron granules were applied at the rate of $50 \mathrm{~g} / \mathrm{m}^{2}$ to 1 entire side of adjacent house 3 , to simulate their normal use.

Results.-Experiments 1 and 2.-As shown in Tables 1 and 2 , the mite population was decimated by dimethoate, fenthion, diazinon, Bay 39007, and ronnel. The mite population recovered more following dimethoate and Bayer 39007 applications than after treatment by the other insecticides. Malathion initially depressed the mite population, but the population recovered rapidly. Kepone depressed the mite population initially and the population recovered in 
Table 2.-Populations of mites (M. muscaedomesticae) and house fly larvae in poultry manure $5 \mathrm{~cm}$ deep following application of larvicides.

\begin{tabular}{|c|c|c|c|c|c|c|c|c|c|c|c|}
\hline \multirow[b]{3}{*}{ Chemical } & \multirow{3}{*}{$\begin{array}{c}\text { Concn }^{\mathrm{a}} \\
(\%)\end{array}$} & \multicolumn{5}{|c|}{ Mean no. mites/sampleb } & \multicolumn{5}{|c|}{ Mean no. fly larvae/sampleb } \\
\hline & & \multirow[b]{2}{*}{ Pretrt. } & \multicolumn{4}{|c|}{ Days after treatment } & \multirow[b]{2}{*}{ Pretrt. } & \multicolumn{4}{|c|}{ Days after treatment } \\
\hline & & & 5 & 14 & 21 & 30 & & 5 & 14 & 21 & 30 \\
\hline Dimethoate & 1.0 & $111.0 \mathrm{a}$ & $0.0 \mathrm{a}$ & $70.3 \mathrm{c}$ & $59.8 \mathrm{c}$ & $17.3 \mathrm{ab}$ & $31.9 \mathrm{ab}$ & $0.7 \mathrm{a}$ & $114.0 \mathrm{a}$ & $91.2 \mathrm{ab}$ & $24.1 \mathrm{ab}$ \\
\hline Fenthion & 1.0 & $53.7 \mathrm{a}$ & $5.2 \mathrm{ab}$ & $5.2 \mathrm{ab}$ & $0.0 \mathrm{a}$ & $0.5 \mathrm{a}$ & $97.1 \mathrm{~b}$ & $6.2 \mathrm{ab}$ & $36.2 \mathrm{a}$ & $81.5 \mathrm{ab}$ & $164.0 \mathrm{c}$ \\
\hline Diazinon & 0.5 & $92.2 \mathrm{a}$ & $1.1 \mathrm{ab}$ & $2.0 \mathrm{ab}$ & $.2 \mathrm{a}$ & $19.0 \mathrm{ab}$ & $57.2 \mathrm{ab}$ & $10.4 \mathrm{~b}$ & $29.4 \mathrm{a}$ & $202.0 \mathrm{~b}$ & $104.0 \mathrm{bc}$ \\
\hline Bay 39007 & 1.0 & $112.0 \mathrm{a}$ & $1.5 \mathrm{ab}$ & $30.5 \mathrm{bc}$ & $60.8 \mathrm{c}$ & $30.5 \mathrm{~b}$ & $57.5 \mathrm{ab}$ & $2.7 \mathrm{a}$ & $57.0 \mathrm{a}$ & $196.0 \mathrm{~b}$ & $103.0 \mathrm{bc}$ \\
\hline Ronnel & 1.0 & $46.8 \mathrm{a}$ & $1.2 \mathrm{ab}$ & $0.6 \mathrm{a}$ & $1.5 \mathrm{ab}$ & $2.6 \mathrm{a}$ & $29.0 \mathrm{ab}$ & $8.1 \mathrm{ab}$ & $36.5 \mathrm{a}$ & $77.0 \mathrm{ab}$ & $108.0 \mathrm{c}$ \\
\hline Malathion & 1.0 & $89.8 \mathrm{a}$ & $17.3 \mathrm{~cd}$ & $58.4 \mathrm{c}$ & $115.0 \mathrm{c}$ & $38.9 \mathrm{~b}$ & $16.4 \mathrm{a}$ & $37.8 \mathrm{bc}$ & $24.7 \mathrm{a}$ & $196.0 \mathrm{~b}$ & $36.5 \mathrm{bc}$ \\
\hline Kepone & 3.0 & $99.0 \mathrm{a}$ & $6.0 \mathrm{c}$ & $8.1 \mathrm{~b}$ & $12.2 \mathrm{bc}$ & $2.5 \mathrm{a}$ & $53.4 \mathrm{ab}$ & $5.0 \mathrm{ab}$ & $54.7 \mathrm{a}$ & $16.2 \mathrm{a}$ & $128.0 \mathrm{c}$ \\
\hline Dichlorvos & .5 & $62.7 \mathrm{a}$ & $36.4 \mathrm{de}$ & $115.0 \mathrm{c}$ & $30.3 \mathrm{c}$ & $2.5 \mathrm{a}$ & $45.2 \mathrm{ab}$ & $159.0 \mathrm{c}$ & $81.0 \mathrm{a}$ & $28.6 \mathrm{ab}$ & $13.2 \mathrm{a}$ \\
\hline Ciodrin & 1.0 & $143.0 \mathrm{a}$ & $60.3 \mathrm{e}$ & $109.0 \mathrm{c}$ & $32.4 \mathrm{c}$ & $66.8 \mathrm{~b}$ & $137.0 \mathrm{~b}$ & $115.0 \mathrm{c}$ & $90.4 \mathrm{a}$ & $114.0 \mathrm{ab}$ & $131.0 \mathrm{c}$ \\
\hline Naled & 1.0 & $113.0 \mathrm{a}$ & $57.7 \mathrm{e}$ & $74.4 \mathrm{c}$ & $52.4 \mathrm{c}$ & $10.3 \mathrm{ab}$ & $55.6 \mathrm{ab}$ & $231.0 \mathrm{c}$ & $68.5 \mathrm{a}$ & $156.0 \mathrm{~b}$ & $142.0 \mathrm{c}$ \\
\hline Untreated & & $91.3 \mathrm{a}$ & $38.4 \mathrm{c}$ & $87.0 \mathrm{c}$ & $12.1 \mathrm{bc}$ & $5.5 \mathrm{ab}$ & $26.2 \mathrm{a}$ & $27.1 \mathrm{~b}$ & $68.7 \mathrm{a}$ & $36.4 \mathrm{ab}$ & $175.0 \mathrm{c}$ \\
\hline
\end{tabular}

a Applied by sprinkling can at the rate of 0.5 liter $/ \mathrm{m}^{2}$. Pretreatment counts August 4 . Treated August 5 . Manure removed July 14 .

b Each mean was based on 4 replicates. Data were transformed to in $(\mathrm{X}+1)$ prior to analysis of variance. Means followed by the same letter in each column were not significantly different at the $5 \%$ level (Duncan's multiple range test).

Experiment 1, but remained low in Experiment 2. Dichlorvos, Ciodrin ${ }^{\circledR}$, and naled had little effect on the mite population.

Control of fly larvae was generally poor. This was most clearly evident in Experiment 2. In that experiment the $5-\mathrm{cm}$ accumulation of manure provided an excellent fly breeding medium, more so than the 60$\mathrm{cm}$ accumulation in Experiment 1 . At the time of the 14-day counts, there were no significant differences in numbers of fly larvae among the treatments. Subsequent counts became increasingly erratic as the physical condition of the manure changed. Temporary larval control was demonstrated by the 5-day counts. Dimethoate and Bay 39007 gave good control, while fenthion, ronnel, Kepone, and diazinon gave some control. Malathion, dichlorovos, Ciodrin, and naled gave no control.

Experiment 3.-As shown in Table 3, both concentrations of SD 8447 caused a significant reduction in the numbers of mites and prevented the increase in number of fly larvae that occurred in the untreated areas 7 days after treatment. Since the number of mites and fly larvae declined in both the treated and untreated areas after 14 days, the experiment was

Table 3.-Populations of mites (M. muscaedomesticae) and house fly larvae in poultry manure following application of SD 8447 .

\begin{tabular}{|c|c|c|c|c|c|c|}
\hline \multirow{3}{*}{$\begin{array}{l}\text { Concn }^{2} \\
(\%)\end{array}$} & \multicolumn{3}{|c|}{$\begin{array}{l}\text { Mean no. mites/ } \\
\text { sample }^{\mathrm{b}}\end{array}$} & \multicolumn{3}{|c|}{$\begin{array}{l}\text { Mean no. fly larvae/ } \\
\text { sample }\end{array}$} \\
\hline & \multirow[b]{2}{*}{ Pretrt. } & \multicolumn{2}{|c|}{$\begin{array}{l}\text { Days after } \\
\text { treatment }\end{array}$} & \multirow[b]{2}{*}{ Pretrt. } & \multicolumn{2}{|c|}{$\begin{array}{l}\text { Days after } \\
\text { treatment }\end{array}$} \\
\hline & & 7 & 14 & & 7 & 14 \\
\hline 1.0 & $67.7 \mathrm{a}$ & $7.2 \mathrm{a}$ & $5.0 \mathrm{a}$ & $20.0 \mathrm{a}$ & $41.7 \mathrm{a}$ & $39.7 \mathrm{a}$ \\
\hline 0.5 & $68.6 \mathrm{a}$ & $4.2 \mathrm{a}$ & 8.7 a & $18.4 \mathrm{a}$ & 39.8 a & $23.7 \mathrm{a}$ \\
\hline Untreated & $81.3 \mathrm{a}$ & $90.1 \mathrm{~b}$ & $16.2 \mathrm{a}$ & $18.2 \mathrm{a}$ & $227.0 \mathrm{~b}$ & $15.4 \mathrm{a}$ \\
\hline
\end{tabular}

a Applied by sprinkling can at the rate of $0.5 \mathrm{liter} / \mathrm{m}^{2}$. Pretreatment counts and treatment made on August 19. Manure accumu lated since July 26.

$\mathrm{b}$ Each mean was based on 4 replications. Data were transformed to $\ln (\mathrm{X}+1)$ prior to analysis of variance. Means followed by the to $1 \mathrm{n}$ ( $\mathrm{X}+\mathrm{l}$ prior $5 \%$ level (Duncan's multiple range test.) ended. This was about September 1, when a cool period occurred and erratic fly populations were to be expected.

Experiment 4.-The dry formulations of Kepone, diazinon, and Zytron were toxic to the mites, and only Kepone provided temporary fly control. However, at the time of the 14-day counts there were no significant differences in the fly populations among the treatments (Table 4). The very wet manure favored fly development, was unfavorable to the mites, and probably decreased the effectiveness of the insecticides.

Experiment 5.-Zytron granules, broadcast on the manure at 50 and $100 \mathrm{~g} / \mathrm{m}^{2}$, were toxic to the mites for 30 days and gave a low level of fly control (Table 5 ). Concurrent counts of fly larvae (mean no. larvae/ 0.5 liter of manure) from the treated (50 g Zytron granules $/ \mathrm{m}^{2}$ ) half of the adjacent house were 142 on the day of treatment. At 7, 14, and 21 days after treatment, the counts were 33,37 , and 96 , respectively.

Discussion AND Conclusions.-Three general conclusions are consistent with these data: (1) Destruction of the predaceous macrochelid mite population resulted from the application of most insecticides. The few chemicals which do not destroy the mite population were of little value for control of fly larvae. (2) The mite population increased very slowly following decimation by insecticide treatment, but the numbers of fly larvae increased very rapidly. (3) Insecticides applied to poultry manure resulted in poor control of house fly larvae. Some chemicals gave control for 5 days and on a few occasions for 14 days. Apparently those larvae exposed at the time of treatment or shortly thereafter were killed, but there was little or no residual activity. This may have been due to 1 or more of the following factors: breakdown of the toxicant, inadequate penetration, and continual addition of fresh, untreated droppings.

There was little agreement between the selectivity of these chemicals in laboratory tests (Axtell 1966) and their action on the mites and fly larvae in the poultry manure. Kepone, the most selective chemical among those tested in the laboratory, showed little selectivity in the field and gave only fair control of fly larvae. Dimethoate showed considerable selectivity 
Table 4.-Populations of mites (M. muscaedomesticae) and house fly larvae in poultry manure following broadcast of dry formulations of larvicides.

\begin{tabular}{|c|c|c|c|c|c|c|c|c|}
\hline \multirow{3}{*}{$\begin{array}{l}\text { Chemical and } \\
\text { formulation }\end{array}$} & \multirow{3}{*}{$\begin{array}{c}\% \\
\text { active } \\
\text { ingredient }\end{array}$} & \multirow{3}{*}{$\begin{array}{l}\text { Application } \\
\text { rate } \\
\left(\mathrm{g} / \mathrm{m}^{2}\right)^{\mathrm{a}}\end{array}$} & \multicolumn{3}{|c|}{ Mean no. mites/sample } & \multicolumn{3}{|c|}{ Mean no. fly larvae/sample ${ }^{b}$} \\
\hline & & & \multirow[b]{2}{*}{ Pretrt. } & \multicolumn{2}{|c|}{$\begin{array}{l}\text { Days after } \\
\text { treatment }\end{array}$} & \multirow[b]{2}{*}{ Pretrt. } & \multicolumn{2}{|c|}{$\begin{array}{l}\text { Days after } \\
\text { treatment }\end{array}$} \\
\hline & & & & 5 & 14 & & 5 & 14 \\
\hline Kepone wP & 50 & 200 & $291.0 \mathrm{a}$ & $0.4 \mathrm{a}$ & $20.9 \mathrm{a}$ & 86.7 a & $1.9 \mathrm{a}$ & $71.4 \mathrm{a}$ \\
\hline Diazinon granules & 14 & 200 & $173.0 \mathrm{a}$ & $.5 \mathrm{a}$ & $0.6 \mathrm{a}$ & $109.0 \mathrm{a}$ & $13.8 \mathrm{~b}$ & $134.0 \mathrm{a}$ \\
\hline Zytron granules & 4.4 & 50 & $128.0 \mathrm{a}$ & $.0 \mathrm{a}$ & $.9 \mathrm{a}$ & $96.1 \mathrm{a}$ & $8.9 \mathrm{~b}$ & $132.0 \mathrm{a}$ \\
\hline Untreated & & & $188.0 \mathrm{a}$ & $4.5 \mathrm{~b}$ & $11.0 \mathrm{a}$ & $82.3 \mathrm{a}$ & $24.4 \mathrm{~b}$ & $108.0 \mathrm{a}$ \\
\hline
\end{tabular}

a Pretreatment counts and treatment made on July 15. Manure accumulated since June 15.

b Each mean was based on 4 replicates. Data were transformed to $\ln (\mathrm{X}+1)$ prior to analysis of variance. Means followed by the same letter in each column were not significantly different at the $5 \%$ level (Duncan's multiple range test).

in laboratory test, but in the field it was rated highly toxic to both mites and fly larvae. Ronnel was more toxic to the flies than to the mites in the laboratory tests, but the opposite was true in the field. Diazinon was about equally toxic to both organisms in the laboratory and in the field. Ciodrin and naled were also about equally toxic in the laboratory tests; in the field they were both very low in toxicity to the mites and the fly larvae. Malathion, fenthion, and dichlorvos were slightly more toxic to the mites than to the fly larvae in both the laboratory and field tests. However, malathion gave poor fly control and dichlorvos was very low in toxicity to both the mites and fly larvae in the field. Bay 39007 was considerably more toxic to the mites than to the fly larvae in the laboratory, while in the field it was highly toxic to both.

Treatment of the manure in the poultry houses should be avoided as long as only relatively nonselective chemicals are used for fly control. It is acknowledged that very temporary control of fly larvae may be accomplished with some chemicals, but the resurgence of the fly population is rapid. In the absence of manure-inhabiting predaceous mites, the fly problem may become greater than it was originally. Other biological agents which may be in the manure (e.g. predaceous fly larvae and beetles) or visiting the surface of the manure (e.g. hymenopterous parasites) also are probably destroyed by most insecticide treatments. Manure treatment is undesirable also because the selection pressure on the larvae is likely to cause a greater rate of resistance development than when only the adults are exposed to the insecticide (Bruce and Decker 1950, Decker and Bruce 1951). The use of feed additives to control fly breeding in poultry droppings (Simco and Lancaster 1966) raises serious questions about the effects of these chemicals on the manure ecosystem. This use warrants detailed investigation before any large-scale feed additive program is attempted.

Selectivity may be possible by the choice of application method. Defoliart (1963) achieved satisfactory fly control in dairy barns by treating only small areas which were used by the flies as resting sites. Keiding and benHannine (1965) demonstrated satisfactory control by selective treatment in pig barns. This approach takes advantage of the differences in the nocturnal resting habits of house flies (mostly on the interior, upper surfaces of the structures) and the hymenopterous parasites and dipterous predators (on the vegetation around the buildings) (Anderson and Poorbaugh 1964, Keiding 1965). Selective applications to the upper interior surfaces of the structure would also minimize harm to the predaceous manure-inhabiting mites. It should be acknowledged that a program of selective application might possibly result in a behavioral change in the fly population. Bruce and Decker (1950) reported that, following repeated insecticide treatment, house flies were resting in lower portions of the barns and on the animals instead of on the upper portions. Also, the flies remained in one place instead of walking around. However, Arevad and Mourier (1963) selected flies for differences in vertical resting habits but could not show any behavioral change after 19 generations of selection. More investigation is warranted, since Connolly (1966) was successful in selecting Drosophila for differences in activity after 25 generations.

Integrated control of the house fly is not yet a reality. The refinement of selective application pro-

Table 5.-Populations of mites (M. muscaedomesticae) and house fly larvae in poultry manure $5 \mathrm{~cm}$ deep following application of $4.4 \%$ Zytron granules.

\begin{tabular}{|c|c|c|c|c|c|c|c|c|c|c|}
\hline \multirow{3}{*}{$\begin{array}{l}\text { Applica- } \\
\text { tion rate } \\
\left(\mathrm{g} / \mathrm{m}^{2}\right)^{\mathrm{a}}\end{array}$} & \multicolumn{5}{|c|}{ Mean no mites/sample ${ }^{\mathrm{b}}$} & \multicolumn{5}{|c|}{ Mean no. fly larvae/sampleb } \\
\hline & \multirow[b]{2}{*}{ Pretrt. } & \multicolumn{4}{|c|}{ Days after treatment } & \multirow[b]{2}{*}{ Pretrt. } & \multicolumn{4}{|c|}{ Days after treatment } \\
\hline & & 5 & 14 & 27 & 30 & & 5 & 14 & 21 & 30 \\
\hline 100 & $107.0 \mathrm{a}$ & $1.0 \mathrm{a}$ & $0.6 \mathrm{a}$ & $0.6 \mathrm{a}$ & $0.7 \mathrm{a}$ & $88.3 \mathrm{a}$ & $35.9 \mathrm{a}$ & $26.7 \mathrm{a}$ & $92.3 \mathrm{a}$ & $99.0 \mathrm{a}$ \\
\hline 50 & 82.3 a & $2.4 \mathrm{a}$ & $3.6 \mathrm{~b}$ & $.8 \mathrm{a}$ & $.9 \mathrm{a}$ & 80.9 a & $31.5 \mathrm{a}$ & $26.5 \mathrm{a}$ & $67.2 \mathrm{a}$ & $115.1 \mathrm{a}$ \\
\hline Untreated & $61.0 \mathrm{a}$ & $83.2 \mathrm{~b}$ & $86.4 \mathrm{c}$ & $50.0 \mathrm{~b}$ & $25.3 \mathrm{~b}$ & $114.0 \mathrm{a}$ & $75.0 \mathrm{a}$ & $185.0 \mathrm{~b}$ & $60.1 \mathrm{a}$ & $126.0 \mathrm{a}$ \\
\hline
\end{tabular}

a Pretreatment counts and treatment made on August 5. Manure accumulated since July 11 .

b Each mean was based on 6 replicates. Data were transformed to $\ln (\mathrm{X}+1)$ prior to analysis of variance. Means followed by the same letter in each column were not significantly different at the $5 \%$ level (Duncan's multiple range test). 
cedures, based on more detailed knowledge of fly behavior, should be pursued. Concurrently, more intensive investigations on the manipulation and propagation of biological control agents against the house fly are needed.

Formulations, Sources, and Identities of ChemiCALS.-

Diazinon, $4 \mathrm{lb} / \mathrm{gal}$ EC and 14\% granules, Geigy Chemical Co.

Dichlorvos, 2 lb/gal Ec, Shell Chemical Co.

Dimethoate, $4 \mathrm{lb} /$ gal Ec, American Cyanamid Co.

Fenthion, 4 lb/gal Ec, Chemagro Corp.

Malathion, $5 \mathrm{lb} / \mathrm{gal}$ Ec, American Cyanamid Co.

Naled, $8 \mathrm{lb} / \mathrm{gal}$ Ec, Chevron Chemical Co.

Ronnel, 2 lb/gal Ec, Dow Chemical Co.

Bay 39007 (Baygon ${ }^{\circledR}$ ) $-O$-isopropoxyphenyl methylcarbamate, $1.5 \mathrm{lb} / \mathrm{gal}$ Ec, Chemagro Corp.

Ciodrin ${ }^{\circledR}$-alpha-methylbenzyl 3-hydroxycrotonate dimethyl phosphate, $3.2 \mathrm{lb} / \mathrm{gal}$ Ec, Shell Chemical Co.

Kepone ${ }^{\circledR}$-decachlorooctahydro-1,3,4-metheno-2H cyclobuta $[c d]$ pentalen-2-one, $50 \%$ wP, General Chemical Div.

SD 8447 (Gardona ${ }^{\circledR}$ ) -2-chloro-1-(2,4,5-trichlorophenyl) vinyl dimethyl phosphate, $2 \mathrm{lb} / \mathrm{gal}$ EC, Shell Chemical Co.

Zytron ${ }^{\circledR}-O$-2,4-dichlorophenyl $O$-methyl isopropylphosphoramidothioate, $4.4 \%$ granules, Dow Chemical Co.

\section{REFERENCES CITED}

Anderson, J. R. 1964. The behavior and ecology of various flies associated with poultry ranches in northern California. Proc. California Mosquito Contr. Ass. 32: $30-34$

1965. A preliminary study of integrated fly control on northern California poultry ranches. Proc. California Mosquito Contr. Ass. 33: 42-44.

1966. Recent developments in the control of some arthropods of public health and veterinary importance. Muscoid flies. Bull. Entomol. Soc. Amer. 12 (3) : $342-8$.

Anderson, J. R., and J. H. Poorbaugh. 1964. Observations on the ethology and ecology of various Diptera associated with northern California poultry ranches. J. Med. Entomol. 1 (2) : 131-47.

Arevad, K., and H. Mourier. 1963. Investigations of house fly behavior in relation to new methods of chemical fly control. 1. Laboratory and cage experiment, p. 48-55. In Annu. Rep. 1962-2, Government Pest Infest. Lab., Lyngby, Denmark.

Axtell, R. C. 1963. Effect of Macrochelidae (Acarina: Mesostigmata) on house fly production from dairy cattle manure. J. Econ. Entomol, 56 (3) : 317-21.

1964. Phoretic relationship of some common manureinhabiting Macrochelidae (Acarina: Mesostigmata) to the house fly. Ann. Entomol. Soc. Amer. 57 (5) : 584-7.

1966. Comparative toxicities of insecticides to house fly larvae and Macrocheles muscaedomesticae, a mite predator of the house fly. J. Econ. Entomol. 59(5): 1128-30.
Brady, U. E., Jr., and G. C. LaBrecque. 1966. Larvicides for the control of house flies in poultry houses. J. Econ. Entomol. $59(6)$ : 1521.

Bruce, W. N., and G. C. Decker. 1950. House fly tolerance for insecticides. Soap Sanit. Chem. $26(3)$ : $122-5, \quad 145-7$.

Connolly, K. 1966. Locomotor activity in Drosophila. II. Selection for active and inactive strains. Anim. Behav. 14 (4) : 444-9.

Decker, G. C., and W. N. Bruce. 1951. Illinois Natural History Survey research on housefly resistance to chemicals, p. 25-33. In Conference on Insecticide Resistance and Insect Physiology, Nat. Acad. Sci., Nat. Res. Council Pub. 219.

DeFoliart, G. R. 1963. Preventive spraying schedules for dairy farm fly control. J. Econ. Entomol. 56(5) : 649-54.

Farish, D. J., and R. C. Axtell. 1966. Sensory functions of the palps and first tarsi of Macrocheles muscaedomesticae (Acarina: Macrochelidae), a predator of the house fly. Ann. Entomol. Soc. Amer. $59(1)$ : $165-70$.

Keiding, J. 1965. Observations on the behavior of the house fly in relation to its control. Riv. Parasitol.. $26(1): 45-60$.

Keiding, J., and S. benHannine. 1965. Fly control by selective spraying of wood-work in piggeries, p. 36 . In Annu. Rep. 1964, Government Pest Infest. Lab., Lyngby, Denmark.

Kinn, D. N. 1966. Predation by the mite, Macrocheles muscaedomesticae (Acarina: Macrochelidae), on three species of flies. J. Med. Entomol. 3 (2) : 155-8.

Legner, E. F. 1966. Parasites of the house fly and other filth-breeding Diptera in southern California. J. Econ. Entomol. 59 (44): 999-1001.

Legner, E. F., and H. W. Brydon. 1966. Suppression of dung-inhabiting fly populations by pupal parasites. Ann. Entomol. Soc. Amer. 59 (4) : 638-51.

Legner, E. F., and C. W. McCoy. 1966. The house fly, Musca domestica Linnaeus, as an exotic species in the western hemisphere incites biological control studies. Can. Entomol, $98(3)$ : 243-8.

McCoy, C. W. 1965. Biological control studies of Mus$c a$ and Fannia sp. on southern California poultry ranches. Proc. California Mosquito Contr. Ass. 33: $40-42$.

O'Donnell, A. E., and R. C. Axtell. 1965. Predation by Fuscuropoda vegetans (Acarina: Uropodidae) on the house fly (Musca domestica). Ann. Entomol. Soc. Amer. 58 (3) : 403-4.

Simco, J. S., and J. L. Lancaster, Jr. 1966. Field test to determine the effectiveness of coumaphos as a feed additive to control house fly larvae under caged layers. J. Econ. Entomol. 59(3): 671-2.

Singh, P., W. E. King, and J. C. Rodriquez. 1966. Biological control of muscids as influenced by host preference of Macrocheles muscaedomesticae (Acarina: Macrochelidae). J. Med. Entomol. 3(1) : 79-81. 
